\title{
Analysis of refuse-derived fuel from the municipal solid waste reject fraction and its compliance with quality standards.
}

\author{
Antonio Gallardo ${ }^{\mathrm{a}}$, *Mar Carlos ${ }^{\mathrm{b}}$, M.D. Bovea ${ }^{\mathrm{c}}$, Francisco J. Colomer ${ }^{\mathrm{d}}$, Fernando Albarrán ${ }^{\mathrm{e}}$. \\ ${ }^{a}$ Ph D. Professor. Dept. Mechanical Engineering and Construction. Jaume I University, Av. de Vicent Sos \\ Baynat s/n. 12071 Castelló de la Plana, Spain. E-mail gallardo@uji.es \\ ${ }^{\mathrm{b}} \mathrm{Ph}$ D. Associate Professor. Dept. Mechanical Engineering and Construction. Jaume I University, Av. de \\ Vicent Sos Baynat s/n. 12071 Castelló de la Plana, Spain. E-mail mcarlos@uji.es. Tel. +34 964728114. \\ (Corresponding Author). \\ ${ }^{\mathrm{c}} \mathrm{Ph}$ D. Professor. Dept. Mechanical Engineering and Construction. Jaume I University, Av. de Vicent Sos \\ Baynat s/n. 12071 Castelló de la Plana, Spain. E-mail bovea@uji.es \\ ${ }^{d}$ Ph D. Professor. Dept. Mechanical Engineering and Construction. Jaume I University, Av. de Vicent \\ Sos Baynat s/n. 12071 Castelló de la Plana, Spain. E-mail fcolomer@uji.es \\ e Industrial Engineer. Technical Director. Reciclados de la Plana S.A. (Reciplasa). Partida Regall de \\ L'Avellar, s/n. 12200 Onda (Castellón), Spain. falbarran@ reciplasa.es
}

\begin{abstract}
The final disposal of the Municipal SolidWaste is still a problem in many countries. The lack of space, the generation of leachate, and the emission of greenhouse gases as well as the requirements of the new legislation on waste dissuade the administrations involved from using the landfill option as a possible means of final disposal of MSW. The terms of the European Legislation onwaste management and energy encourage member states to develop waste recovery techniques before sending it to a landfill. Therefore, member states have introduced source separation and mechanical-biological treatment to separate biodegradable recovery fractions (organic, paper-cardboard, plastic packaging, and glass) from the reject fraction, which is afterwards disposed of in landfills. One of the main aims of this study is to analyse the energy recovery properties of the reject fraction from a biological-mechanical treatment plant in Spain. For this purpose, this work presents a physical and chemical characterization of waste reject fraction from a real mechanical-biological treatment plant as well as the metal and halogen content. Additionally, the quality standards of the refused derived fuel processed at the laboratory and the atmospheric emissions of this type of fuel have been determined.
\end{abstract}

Key words: reject, recovery, standard quality, RDF, SRF, MBT

\section{Introduction}

The final disposal of Municipal Solid Waste (MSW) is still a problem in many countries. The increasing price of raw materials as well as the lack of space for new landfills, the problems arising from leachate and the restrictions imposed by the European regulations mean that a number of waste strategies have been produced and are awaiting implementation (Murphy and McKeogh, 2004). A waste hierarchy suggesting the environmental preference of recycling over incineration over landfilling is often put forward and used in waste policy making (Finnveden et al., 2005). From an energy recovery viewpoint, Arafat et al (2013) found that it is best to recycle paper, wood and plastics; to anaerobically digest food and yard wastes; and to incinerate textile 
waste. Eriksson et al (2005) showed that reduced landfilling in favour of increased recycling of energy and materials lead to lower environmental impact, lower consumption of energy resources, and lower economic costs. Landfilling of energy-rich waste should be avoided as far as possible, partly because of the negative environmental impacts from landfilling, but mainly because of the low recovery of resources when landfilling. In this way, Koroneosand Nanaki (2012) pointed out that environmental impacts are decreased when the solid waste management methods include some kind of recovery from waste. The results of their work indicate that paper recycling and anaerobic digestion of food waste is preferable compared to landfilling. Therefore, an integrated system which recovers nutrients, materials and energy from the waste stream, and reduces landfill disposal of organic and recyclable waste reduces GHG emissions very significantly compared to conventional landfill disposal (Menikpura et al., 2013).

Another possible alternative to landfills is to apply thermal treatments to the MSW. Thermal treatment using incineration technology has been proven as an attractive method of waste disposal for many years due to the primary advantages of hygienic control, volume reduction, and energy recovery (Chang et al., 1998). But thermal treatments should not be detrimental to MSW recovery policies, such as reuse and recycling. Domestic and commercial waste must be treated with the aim of utilizing its energy content, while at the same time recycling as much of its material content as possible (Wittmaier et al., 2009). Therefore the MSW that has been collected must first be treated in an industrial plant such as a mechanical-biological treatment (MBT) plant. The main objective of this type of industrial plants is to reduce the content of waste biodegradable organic matter in order to minimize its environmental impacts when landfilled (odour production, self-heating and self-combusting, biogas production, leachate and pathogen growth) (Barrena et al., 2009). Another aim is to recover materials (biowaste is transformed into compost) to comply with the current legislation and to recover as much recyclable material as possible. As a result of the treatment of MSW in a MBT plant, paper and cardboard, cardboard packaging, metal, plastics, glass and biowaste are separated from the residual fraction that cannot be exploited and that is finally dumped in a landfill. But this residual fraction, also called reject fraction (RF), can be profitable from the environmental and economic point of view. It can be turned into a refuse-derived fuel (RDF), which is waste that has been treated (or processed). This process consists in eliminating the non-combustible fraction, reducing its size and moisture content, homogenization of the waste, and in some cases its transformation into pellets. The proper estimation of the energy content of the residual fraction from MBT plants is essential for planning and promoting different methods to decrease its environmental impact, to lower the consumption of energy resources, and to reduce economic costs (Aranda et al., 2012). The RDF is traded and co-burnt in installations for power generation or in manufacturing processes where heat is required. RDF covers a wide range of waste materials which have been processed to comply with guidelines or regulatory or industry specifications mainly to achieve a high calorific value. The term RDF usually refers to the segregated high calorific fraction of processed MSW. In the European Union, it is estimated that the total amount of RDF produced from MSW is about 4-5 million tonnes annually (Grau and Farré, 2011). This production capacity is being increased in many countries thanks to the implementation of new MBT plants. For example, in 2009, there were 120 material recovery and composting facilities in Spain (MMAMRM, 2010) and according to the Spanish Integrated National Waste Plan (PNIR) 2008-2015, an increase in the number of this kind of treatment facilities is foreseen. The main advantages of using RDF as a fuel are an important reduction in the 
volume of waste and the possibility of energy recovery. Recognition of the integrated value of pre-sorting solid waste prior to the incineration process would offer a new perspective in solid waste management that includes the coordination of environmental benefits from solid waste pre-sorting, improved incinerator performance, and the direct revenues from recycled materials (Chang et al., 1998). Nowadays a number of industries are interested in this type of fuel. Many authors agree that the main potential RDF users are the cement and power industries, and industrial boilers (Nithikul et al., 2011). In countries like Germany, energy-intensive industries like cement, paper, chemical production or power generation would be interested in the use of RDF, either as co-combustion in modified existing plants or as mono-combustion in specifically designed boilers(Rotter et al., 2004). Despite the advantages of energy recovery from MSW, this option is the focus of a social debate due to qualms about the acceptability and compatibility of the technological solutions involved, particularly from the point of view of the impact on the atmosphere (Genon and Brizio, 2008), even though nowadays the stringent requirements on air pollution can be controlled by using the existing technology correctly (Porteus, 2001) and that some authors consider that the use of SRF as co-fuel can reduce global warming and acidification potential significantly (Anurag etal., 2007).

The research work presented here is the result of the collaboration between the company Reciclados la Plana S.A (RECIPLASA) and INGRES, which is a research group at the Universitat Jaume I. RECIPLASA manages a MBT located in Onda (Spain). The main aim of this work is to analyse the possibilities of obtaining RDF from the RF in the mechanical selection stage and to define its physical and chemical properties. After the sampling process, the work has been structured in four sections. First of all, the physical and chemical properties of the waste reject fraction are determined. Second, the transformation and quality requirements to be met before RF can be used as a fuel are studied. Third, the legislation requirements in terms of energetic recovery are also presented. Finally, the effects of atmospheric emissions from using RDF are compared with the effects of other traditional fuels.

\section{Methodology}

As mentioned above, the RDF samples were taken from the MBT plant situated in Onda, a town in the province of Castellón, on the east coast of Spain. This plant treats the MSW collected from 25 municipalities with a total of approximately 400,000 inhabitants, which represents $464 \mathrm{t}$ of MSW treated per day. According to the MSW management hierarchy, the aims of Onda's MBT plant are, on the one hand, to recover high quality materials and, on the other, to separate the biodegradable fraction. Using manual and mechanical processes, the MSW is divided into the main recovered fractions such as organic matter, paper, metals, plastics and bulky elements as showed in figure 1. Paper, plastic and bulky elements then undergo manual separation, the organic fraction is removed mechanically in a trommel and metals are removed by passing them through magnetic separators. After undergoing the correspondent treatments, paper and cardboard, metals and plastic are sent to another type of companies that process them or use them as raw material. The organic matter is separated and stabilized using biological treatments to produce compost. Finally, the RF is obtained downstream from the mechanical treatment process. The RF is formed by all the MSW materials that are not separated in the previous classification stages as they fail to satisfy the quality requirements needed to be recovered or recycled. At the MBT 
in Onda, it represents $43.10 \%$ of the initial volume of MSW treated and it is finally dumped on a landfill.

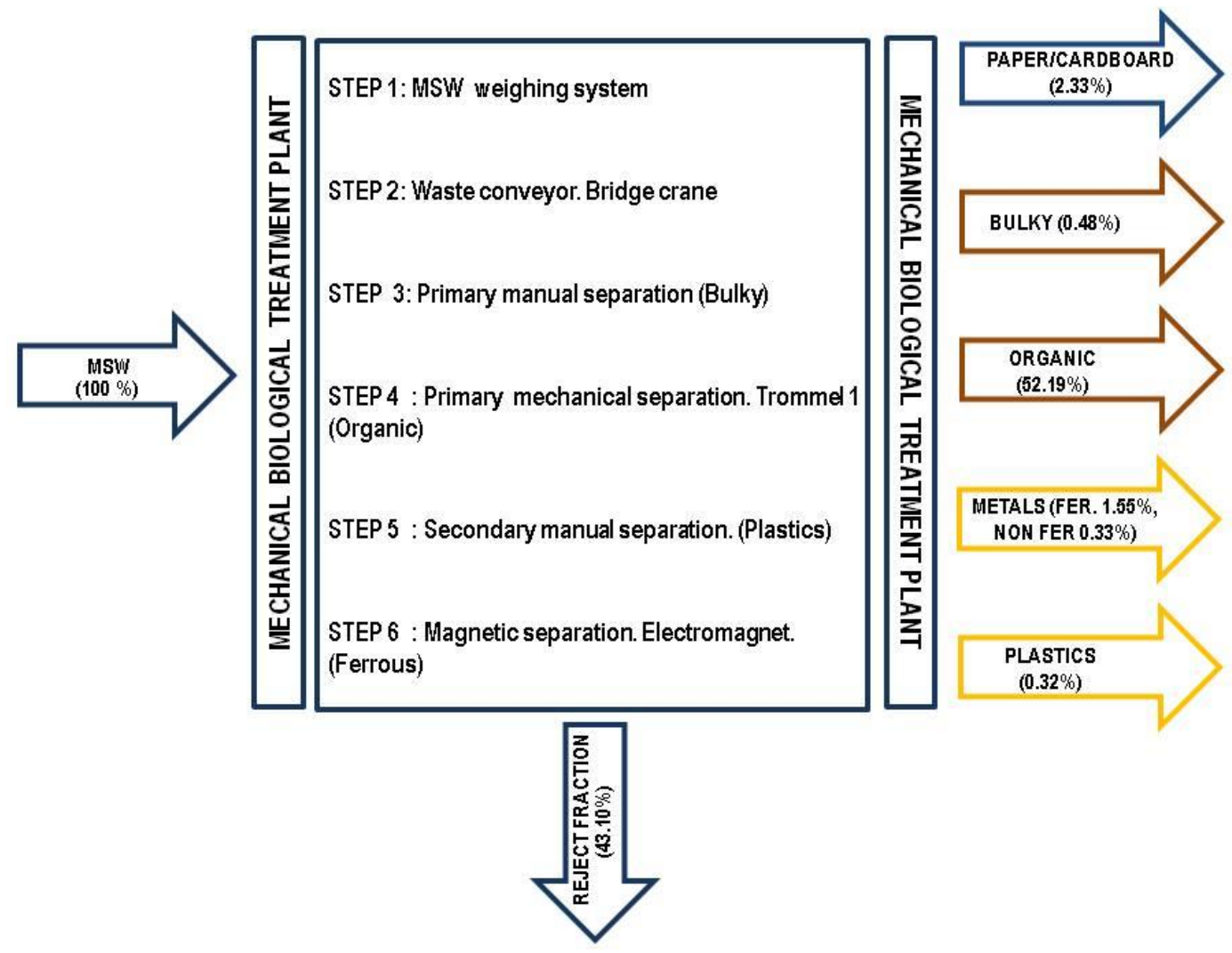

Figure 1. Waste separation in Onda's MBT plant.

The experimental methodology is divided into three sections: collection of the RF sample, physical characterization of the RF sample, and chemical characterization of the RF sample.

\subsection{Sampling Process}

The MBT plant in Onda generates $200 \mathrm{t}$ of RF per day. This plant works six days a week, as there is no production on Sundays. The sampling process was carried out during the months of April, May and June (spring season). Some representative samples were taken in two non-consecutive weeks. The weeks were chosen taking into account that there were no special events in them that could distort the results. Thus, twelve samples were taken, which correspond to 14 days' MSW generation.

In the Onda MBT plant, the RF is packaged in $1600 \mathrm{~kg}$ bales. It is calculated that between 125 and 130 bales are sent to the landfill every day. There was no information about the composition of the RF from the MBT plant in Onda from previous studies or from similar Spanish plants that could be used to calculate the number of bales needed to carry out the analysis. Hence, five bales were taken from the plant every day and analysed in the laboratory. The bales were collected at equidistant times throughout the working day. Therefore, $8,000 \mathrm{~kg}$ of RF were used every day to extract the sample that would later be analysed in the laboratory. The bales were mixed in a sealed area and spread to form a circle which was divided into quarters. Two opposite sectors were 
taken and a new circle was formed with them. The new circle was again divided into quarters. The process was repeated until the sample weight was approximately $125 \mathrm{~kg}$, as shown in Table 1.

Table 1. Sample size reduction from five bales of RF

\begin{tabular}{llllllll}
\hline Quarter number & $\mathbf{0}$ & $\mathbf{1}$ & $\mathbf{2}$ & $\mathbf{3}$ & $\mathbf{4}$ & $\mathbf{5}$ & $\mathbf{6}$ \\
\hline Sample weight (kg) & 8,000 & 4,000 & 2,000 & 1,000 & 500 & 250 & 125 \\
\hline
\end{tabular}

\subsection{Reject Fraction Physical Characterization}

The RF extracted at the plant was packaged in big-bags and taken to the laboratory. The big-bags were weighed and afterwards they were emptied onto the triage table. The manual selective triage of the RF makes it possible to know the physical composition of the RF based on weight percentages (Figure 2), the size distribution, and the moisture content.

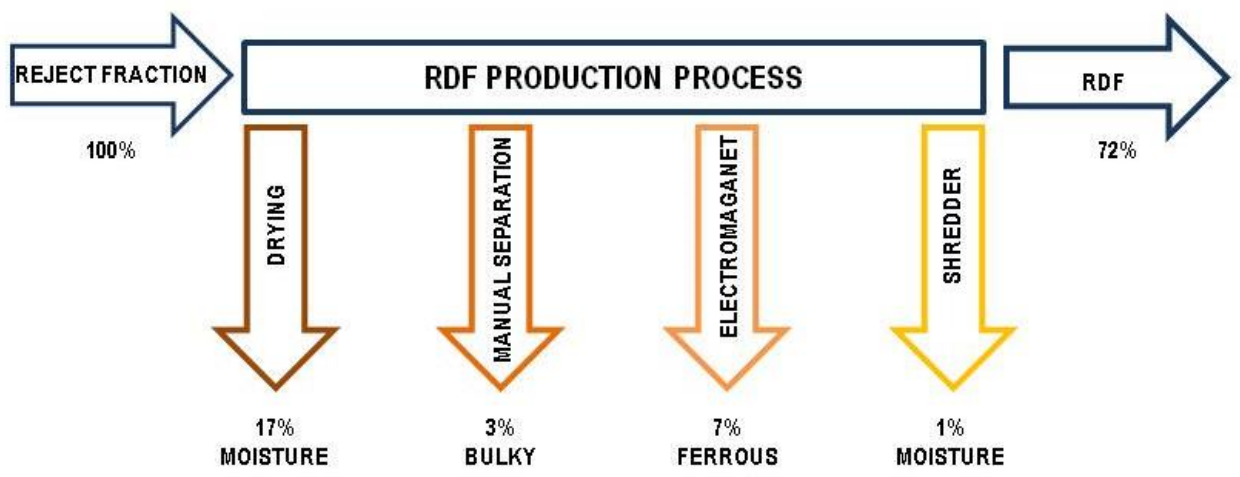

Figure 2. RDF Production Process.

The selected materials in the RF were classified in the categories shown in Table 2. The composition and the moisture depend on the origin of the generation, so this characterization is very important to evaluate the possibilities of RF recovery.

The moisture content allows both the waste water weight and the waste dry matter weight to be calculated. The average moisture value for the 12 sampling days considered was $34.46 \%$ and the standard deviation was 3.25. The moisture content affects the calorific value, which makes it necessary to establish a previous thermal treatment. The moisture value was obtained according to CEN/TS 15414-3 (2011). Once the moisture value is known, it is simple to calculate the dry sample (DS) average composition from the Wet Sample (WS) average composition. All these values are summarized in Table 2. 
Table 2: Wet RF categories and composition

\begin{tabular}{|c|c|c|c|c|c|c|c|}
\hline \multicolumn{2}{|c|}{ Category } & $\begin{array}{c}\text { WS average } \\
\text { composition } \\
(\%)\end{array}$ & $\begin{array}{c}\text { WS } \\
\text { Standard } \\
\text { deviation } \\
(\%)\end{array}$ & $\begin{array}{c}\text { Moisture } \\
(\%)\end{array}$ & $\begin{array}{c}\text { Moisture } \\
\text { Standard } \\
\text { deviation } \\
(\%)\end{array}$ & $\begin{array}{c}\text { DS average } \\
\text { composition } \\
(\%)\end{array}$ & $\begin{array}{c}\text { DS } \\
\text { Standard } \\
\text { deviation } \\
(\%)\end{array}$ \\
\hline \multicolumn{2}{|c|}{$\begin{array}{l}\text { Food and gardening } \\
\text { waste }\end{array}$} & 16.84 & 4.52 & 54.12 & 5.53 & 12,34 & 3,37 \\
\hline \multicolumn{2}{|c|}{ Sanitary cellulose } & 4.23 & 1.48 & 56.65 & 9.96 & 2.75 & 1.07 \\
\hline \multicolumn{2}{|c|}{$\begin{array}{l}\text { Paper and } \\
\text { cardboard }\end{array}$} & 32.15 & 3.72 & 41.64 & 4.67 & 28.64 & 3.88 \\
\hline \multirow[t]{6}{*}{ Plastics } & PET (1) & 3.09 & 1.68 & 11.75 & 3.25 & 4.19 & 1.19 \\
\hline & HDPE (2) & 2.40 & 1.30 & 6.46 & 1.31 & 3.38 & 0.85 \\
\hline & LDPE (4) & 12.17 & 6.62 & 27.63 & 5.55 & 13.48 & 2.53 \\
\hline & $\operatorname{PPc}(5)$ & 1.05 & 0.57 & 12.35 & 6.84 & 1.39 & 0.40 \\
\hline & PS (6) & 1.01 & 0.55 & 18.38 & 4.28 & 1.25 & 0.38 \\
\hline & Others & 2.47 & 1.34 & 9.04 & 6.54 & 3.46 & 1.79 \\
\hline \multicolumn{2}{|l|}{ Glass } & 1.13 & 0.59 & 1.43 & 0.71 & 1.71 & 0.90 \\
\hline \multicolumn{2}{|c|}{ Tetra Brick } & 2.03 & 1.12 & 29.40 & 3.82 & 2.19 & 1.20 \\
\hline \multicolumn{2}{|l|}{ Wood } & 3.25 & 1.42 & 31.27 & 6.99 & 3.34 & 1.29 \\
\hline \multicolumn{2}{|c|}{ Footwear } & 1.41 & 0.99 & 20.69 & 20.01 & 1.75 & 1.39 \\
\hline \multicolumn{2}{|l|}{ Textile } & 7.91 & 2.50 & 30.83 & 7.22 & 8.28 & 2.51 \\
\hline \multicolumn{2}{|c|}{ Rubber and leather } & 0.60 & 0.39 & 12.86 & 11.86 & 0.84 & 0.57 \\
\hline \multirow[t]{3}{*}{ Metals } & Ferrous & 3.28 & 1.98 & 12.04 & 3.82 & 4.62 & 3.67 \\
\hline & $\begin{array}{l}\text { Non- } \\
\text { Ferrous }\end{array}$ & 0.81 & 0.49 & 15.20 & 8.26 & 0.92 & 0,75 \\
\hline & $\begin{array}{l}\text { Aluminium } \\
\text { Foil }\end{array}$ & 0.30 & 0.18 & 28.67 & 5.46 & 0.28 & 0,19 \\
\hline \multicolumn{2}{|c|}{$\begin{array}{l}\text { Hazardous } \\
\text { materials }\end{array}$} & 0.15 & 0.10 & 14.56 & 7.26 & 0.20 & 0.14 \\
\hline \multicolumn{2}{|c|}{$\begin{array}{l}\text { Soil, ash and } \\
\text { ceramics }\end{array}$} & 1.42 & 0.78 & 11.03 & 7.99 & 1.86 & 0.83 \\
\hline \multicolumn{2}{|l|}{ Others } & 2.29 & 2.40 & 7.77 & 4.75 & 3.12 & 3.17 \\
\hline
\end{tabular}

From the composition point of view, first of all, food and gardening waste makes up the largest fraction of the RF, at $16.98 \%$. The trommel screen aperture diameter was $8 \mathrm{~cm}$. It could be reduced improving the splitting open refuse bags techniques. Food and gardening and sanitary cellulose fractions contribute to increase the level of moisture in the sample. Therefore, they must be separated more efficiently to reduce the moisture. Second, paper and cardboard is the fraction with the highest weight percentage, $32.15 \%$. This is due to the manual pre-sorting carried out in the plant, which simply recovers big boxes, and no other sorting exists to reduce this fraction downstream of the trommel. Paper and cardboard also has a high moisture content. The plastics fraction accounts for $22.2 \%$ of the RF composition. This is a fraction with a lower moisture content, $19.80 \%$. Within the plastics fraction, Low Density Polyethylene (LDPE), the material used for film bags, has the highest moisture content, $27.63 \%$, because after using these bags they are usually impregnated with liquid. The percentage of glass content in the RF is small compared to the other fractions. In this case the selective collection has allowed a great amount of this material to be recovered. The weight percentage of the metal fraction is $4.39 \%$ but it could be reduced by improving the electromagnet system as well as the Foucault separator. The moisture values of this fraction are so high due to the leachate in the aluminium foil and in the cans. The presence of hazardous materials such as 
batteries, cosmetics, inks and drugs in the RF ( $0.15 \%$ as shown in Table 2$)$ is lower than in the Spanish MSW (approximately 0.8-1\%) (Elías, 2004). The reason for the reduction in the amount of hazardous materials is that part of them have been previously separated out at the MBT plant with the plastic and metal fractions. The inert fraction is mainly composed of soil, ashes and ceramics. The total composition percentage of these materials in the RF that was analysed is $9.23 \%$ and its moisture content is very low, $11.03 \%$. The last item in Table 2 is the term "Others", which corresponds to waste that was not considered in the previous categories, such as electric and electronic waste, foam or products made of different materials. In order to use the RF as a fuel it must be considered a combination of combustible and non-combustible materials. The noncombustible fraction (NCF) consists of four categories: glass; metals; soil, ash and ceramics; and others. The combustible fraction (CF) is composed of the rest of the categories listed in Table 2. The CF represents a high percentage of the total RF $90.70 \%$ considering the wet sample and $87.49 \%$ taking into account the dry sample. The $\mathrm{NCF}$ is a fraction that is easy to segregate from the RF simply by using mechanical treatments as sieves and densimetric tables.

\subsection{Reject Fraction Chemical Characterization}

Chemical characterization consists in defining the elemental components of the RF, which allows the different options for processing and recovering RF to be evaluated. Therefore, the sulphur (S), carbon $(\mathrm{C})$, nitrogen $(\mathrm{N})$, ash, heavy metals and halogens contents as well as the Net Calorific Value (NCV) were analysed. The S, C and $\mathrm{N}$ contents are especially important when applying thermal treatments to the RF due to the formation of $\mathrm{SO}_{2}, \mathrm{CO}_{2}$ and $\mathrm{NO}_{\mathrm{x}}$ which cause photochemical smog and the greenhouse effect. C and S contents were analysed using the SC-144DR analyser. This analyser determines $\mathrm{C}$ and $\mathrm{S}$ contents as a result of combustion of the sample. The $\mathrm{SO}_{2}$ and $\mathrm{CO}_{2}$ generated were determined using infrared spectrophotometry. The $\mathrm{N}$ content was also determined as a result of the combustion of the sample, but in this case the $\mathrm{NO}_{\mathrm{x}}$ was reduced to $\mathrm{N}_{2}$, and $\mathrm{N}_{2}$ was measured in a thermal conductivity detector (TCD). The twelve samples of dry $\mathrm{CF}$ were extracted and the mean values and their variance were calculated as shown in Table 3. In order to do that, twelve samples were first prepared (the different materials found in the samples were mixed in their corresponding proportions). After preparing the samples, they were shredded in a mill in several different stages, until the grain size of the sample was $1 \mathrm{~mm}$.

The dry sample of CF presents a low value of $\mathrm{S}, 0.1 \%$, which is even lower than the amount of $\mathrm{S}$ in the best quality coals, with a value of about $0.8-1 \%$. The $\mathrm{N}$ content is also lower than that of coal. The composition and amount of ash depend on the incineration conditions. The percentage of ash makes it possible to know the amount of unburned product and therefore to foresee its management. Its composition and its quantity influence the combustion technology to be used, the characteristics of the kiln, the temperature and the extraction method (Tortosa et al., 2007). The methodology employed in this case is CEN/TS 15403 (2011). As shown in Table 3, the percentage of ash is about $10 \%$, a reasonable value for this type of material. The Carbon, Hydrogen and Nitrogen content have been determined according to CEN/TS 15407 (2011). 
Table 3. Percentage of S, C, N and ash in the combustible fraction and Net Calorific Value

\begin{tabular}{lcc}
\hline & $\begin{array}{c}\text { Dry CF sample } \\
\text { average }\end{array}$ & $\begin{array}{c}\text { Dry CF sample } \\
\text { standard deviation }\end{array}$ \\
\hline S (\%) & 0.10 & 0.025 \\
C (\%) & 54.87 & 2.62 \\
N $(\%)$ & 0.90 & 0.21 \\
Ash $(\%)$ & 10.69 & 2.07 \\
NCV $\left(\mathbf{k c a l} \cdot \mathbf{~ k g}^{-1}\right)$ & $5,101.7$ & 288.4 \\
\hline
\end{tabular}

On the one hand, the calorific value of the RF is essential to be able to evaluate the viability of using the RF as a fuel and to determine its energetic efficiency. On the other hand, in many kilns, their design and control depend on the calorific value of the material used as fuel (Erol et al., 2010). The calorific value of waste is the energy released per unit weight or volume as a result of the combustion of the waste material in the presence of oxygen. In order to calculate the net calorific value, the water vaporization latent heat must be subtracted from the high calorific value. The NCV of the combustion fraction was calculated in accordance with CEN/TS 15400 (2011) using a constant volume bomb calorimeter. The results presented in Table 3 show that the dry $\mathrm{CF}$ can be a good fuel compared to anthracite or lignite.

Heavy metals are inorganic chemical pollutants and can present an ionic or molecular form. As a result of normal human activity, heavy metals are present in many types of solid waste produced by the industrial sector and in a lower concentration in MSW, especially in packaging composition, as shown in Table 4 . There are a great variety of heavy metals that can cause serious damage to human health and the environment due to their cumulative toxic properties. The European legislation on industrial emissions, Directive 2010/75/EU, states that it is important to control the concentrations of some metals such as Cadmium (Cd), Thallium (Tl), Antimony (Sb), Astatine (As), Lead ( $\mathrm{Pb}$ ), Chromium (Cr), Cobalt (Co), Copper $(\mathrm{Cu})$ Mercury ( $\mathrm{Hg})$, Manganese (Mn), Nickel (Ni) and Vanadium (Vn), as well as Hydrochloric and Hydrofluoric acids. Metal contents were measured using the Inductively Coupled Plasma Mass Spectrometry (ICP-Mass) technique.

Some halogens are also controlled in the combustion processes because they are potential air pollutants and they can cause problems in the combustion chamber. For example, Chlorine produces the formation of deposits in the kiln and oxidation on the inner layer of the kiln (Öhman and Nordin, 1998). As set out in Directive 2010/75/EU, it is important to control Chlorine $(\mathrm{Cl})$ and Fluorine $(\mathrm{F})$. In this research work, halogens were determined using ion chromatography. Heavy metal and halogen contents are more difficult to calculate due to the low concentrations and the heterogeneity of the sample. These facts are reflected in the high values of the standard deviation. As shown in Table 4, Mn, $\mathrm{Cr}$ and $\mathrm{Cu}$ are the metals with the highest presence. The high $\mathrm{Cr}$ content is due to the tanning industry present in the zone, while the high $\mathrm{Cl}$ level is due to plastic packaging. 
Table 4. Heavy metal and halogen contents in the combustion fraction

\begin{tabular}{lcc}
\hline $\begin{array}{c}\text { Heavy } \\
\text { Metal or } \\
\text { Halogen }\end{array}$ & $\begin{array}{c}\text { Dry CF } \\
\text { sample } \\
\text { average } \\
\left(\mathbf{m g} \cdot \mathbf{k g}^{-1}\right)\end{array}$ & $\begin{array}{c}\text { Dry CF } \\
\text { sample } \\
\text { standard } \\
\text { deviation } \\
\left(\mathbf{m g}^{-\mathbf{k g}^{-1}}\right)\end{array}$ \\
\hline $\mathbf{V}$ & 5.95 & 4.22 \\
$\mathbf{C r}$ & 135.49 & 98.7 \\
$\mathbf{M n}$ & 136.27 & 91.25 \\
$\mathbf{C o}$ & 4.63 & 2.28 \\
$\mathbf{N i}$ & 19.92 & 9.95 \\
$\mathbf{C u}$ & 108.92 & 45.21 \\
$\mathbf{A s}$ & 21.41 & 13.63 \\
$\mathbf{C d}$ & 9.80 & 7.15 \\
$\mathbf{S b}$ & 55.85 & 27.20 \\
$\mathbf{H g}$ & 82.66 & 29.97 \\
$\mathbf{T l}$ & 1.33 & 1.23 \\
$\mathbf{P b}$ & 63.86 & 27.64 \\
$\mathbf{C l}$ & 3359.25 & 509 \\
$\mathbf{F}$ & 62.20 & 56.17 \\
\hline
\end{tabular}

\section{Results and Discussion}

The main application of the CF of the RF is its utilization as a fuel in the industrial and energy sectors. The discussion about characteristics and quality standards associated with waste processing for fuel production is led by three participating groups: the RDF producers, potential RDF customers, and the respective authorities. Furthermore, the RDF production must take into account some basic rules. It must ensure the protection of the combustion facilities as well as the industry final product. To decide whether the RDF created from the RF of MSW treatment plants can be used as a fuel in the different technologies currently in use, it is necessary to know its physical and chemical characteristics as well as its thermal behaviour (Kaliyan and Morey, 2009). Moreover, the energetic and mineral RDF content must be stable enough to allow optimal operation in industry. The physical state of the RDF must allow safe handling and storage and, above all, the chemical and physical quality of the RDF must satisfy environmental specifications. In order to ensure a predefined quality, the RDF is subject to standards. Therefore some countries like Germany, Italy or Finland have defined their own quality standards for this type of products. In Germany the control of RDF manufacturing was verified by means of RAL-GZ 724 (2012) where average and percentile limit values of 80\% were defined. In Italy, the UNI 9903 (2004) regulation sets the medium and high physical-chemical properties of RDF. In Finland, SFS 15358 (2011) has defined three quality levels for each parameter, Class I being the most stringent, and it also sets out the characteristics of the production process. Other countries like Spain, Switzerland or UK have defined specific quality standards covering the use of the RDF in cement kilns in order to adapt it to the process correctly. The European Association of Waste Thermal Treatment Companies for Specialised Waste (EURITS, 1996) has published criteria for waste co-incinerated in cement plants as a substitute fuel that countries like Belgium are currently using. In fact, a experiment 
technique determined the emissions of various pollutants (PAHs, PCDD/Fs, metals, acid gases, etc.) in a cement kiln fed on different proportions of SRF material. It showed that in the cement kiln, all emitted pollutants were under the legal limits. No correlation between SRF input and metal emission was observed (Conesa et al., 2011).

Table 5 shows some of these quality standards and the Onda plant's parameters so that they can be compared. Results in Table 5 show that the CF satisfies the NCV standard quality requirements (except for Switzerland), so it could be used as a fuel without any problems. The ash content only satisfies the Italian requirements, so this parameter should be improved. Regarding $\mathrm{Cl}$ and $\mathrm{F}$, the dry $\mathrm{CF}$ has a very low percentage of them, so it satisfies almost all the regulations considered in this work. It also satisfies $\mathrm{S}$ and $\mathrm{N}$ limit contents (except EURITS limits, in the case of $\mathrm{N}$ ). In contrast, not all the heavy metals satisfy the preset requirements from the different regulations. Regarding the quality standards of the Spanish cement kiln, except for the ash content, it satisfies all the limit parameters. Nevertheless, the ash percentage could easily be reduced if the inert material (dust and dirt) that covers all the materials that form the RF were previously eliminated by some mechanical treatment such as sieving.

Table 5. RDF quality standards

\begin{tabular}{|c|c|c|c|c|c|c|c|}
\hline \multirow[t]{2}{*}{ Parameters } & \multirow[t]{2}{*}{ Unit } & \multirow[t]{2}{*}{ Dry CF } & \multicolumn{2}{|c|}{ General Standards } & \multicolumn{3}{|c|}{ Cement Kiln Standards } \\
\hline & & & Italy & $\begin{array}{l}\text { Finland } \\
\text { Quality I }\end{array}$ & Spain & EURITS & Switzerland \\
\hline Moisture & $\%$ & $\mathbf{0}$ & $<25$ & & $<1$ & & $<10$ \\
\hline Net Calorific & $\mathrm{MJ} \cdot \mathrm{kg}^{-1}$ & 20.6 & 15 & & & 15 & $25.1-31.4$ \\
\hline & $\mathrm{kcal} \cdot \mathrm{kg}^{-1}$ & $5,101.7$ & 3,588 & & $\begin{array}{c}>5,00 \\
0\end{array}$ & 3,588 & $6,005-7,512$ \\
\hline Ash content & $\%$ & 10.69 & 20 & & $<<10$ & 5 & $0.6-0.8$ \\
\hline $\mathrm{Cl}$ & $\%(\mathrm{~m} / \mathrm{m})$ & 0.335 & 0.9 & $<0.15$ & & 0.5 & $<1$ \\
\hline $\mathrm{S}$ & $\%(\mathrm{~m} / \mathrm{m})$ & 0.103 & 0.6 & $<0.20$ & $<3$ & 0.4 & $<0.5$ \\
\hline $\mathrm{N}$ & $\%(\mathrm{~m} / \mathrm{m})$ & 0.901 & & $<1.0$ & $<3$ & 0.7 & \\
\hline $\mathrm{F}$ & $\%(\mathrm{~m} / \mathrm{m})$ & 0.0062 & & & & 0.1 & \\
\hline $\mathrm{K}, \mathrm{Na}$ & $\%(\mathrm{~m} / \mathrm{m})$ & & & $<0.20$ & & & \\
\hline $\mathrm{Hg}$ & $\mathrm{mg} \cdot \mathrm{kg}^{-1}$ & 82.66 & & $<0.1$ & & & $<5$ \\
\hline $\mathrm{Cd}$ & $\mathrm{mg} \cdot \mathrm{kg}^{-1}$ & 9.80 & & $<1.0$ & & & $<5$ \\
\hline $\mathrm{Pb}$ & $\mathrm{mg} \cdot \mathrm{kg}^{-1}$ & 63.86 & 200 & & $\begin{array}{c}<2,50 \\
0\end{array}$ & & $<100$ \\
\hline $\mathrm{Cu}$ & $\mathrm{mg} \cdot \mathrm{kg}^{-1}$ & 108.92 & 300 & & & & \\
\hline $\mathrm{Mn}$ & $\mathrm{mg} \cdot \mathrm{kg}^{-1}$ & 136.27 & 400 & & & & \\
\hline $\mathrm{Cr}$ & $\mathrm{mg} \cdot \mathrm{kg}^{-1}$ & 135.49 & 100 & & $\begin{array}{c}<1,50 \\
0\end{array}$ & & $<30$ \\
\hline $\mathrm{Zn}$ & $\mathrm{mg} \cdot \mathrm{kg}^{-1}$ & & 500 & & & 500 & $<2,000$ \\
\hline $\mathrm{Ni}$ & $\mathrm{mg} \cdot \mathrm{kg}^{-1}$ & 19.92 & 40 & & & & $<10$ \\
\hline As & $\mathrm{mg} \cdot \mathrm{kg}^{-1}$ & 21.411 & 9 & & & & \\
\hline $\mathrm{Ba}$ & $\mathrm{mg} \cdot \mathrm{kg}^{-1}$ & & & & $\begin{array}{c}<5,00 \\
0\end{array}$ & & \\
\hline $\mathrm{Cd}+\mathrm{Hg}$ & $\mathrm{mg} \cdot \mathrm{kg}^{-1}$ & 92.46 & 7 & & & & \\
\hline $\mathrm{Br} / \mathrm{I}$ & $\mathrm{mg} \cdot \mathrm{kg}^{-1}$ & & & & & 0,01 & \\
\hline $\mathrm{Hg} / \mathrm{Ti}$ & $\mathrm{mg} \cdot \mathrm{kg}^{-1}$ & & & & & 2 & \\
\hline $\mathrm{As}, \mathrm{Se}(\mathrm{Te})$ & $\mathrm{mg} \cdot \mathrm{kg}^{-1}$ & 87.06 & & & & 10 & \\
\hline
\end{tabular}




\begin{tabular}{lcccc}
\hline $\mathrm{Cd}, \mathrm{Sb}$ & & & 20 \\
$\mathrm{Mo}$ & $\mathrm{mg} \cdot \mathrm{kg}^{-1}$ & & 200 & \\
$\mathrm{~V}, \mathrm{Cr}, \mathrm{Co}, \mathrm{Ni}$, & $\mathrm{mg} \cdot \mathrm{kg}^{-1}$ & $\mathbf{4 7 5 . 0 4}$ & & \\
$\mathrm{Cu}, \mathrm{Pb}, \mathrm{Mn}$, & & & & $<50$ \\
$\mathrm{Sn}$ & & & & $<300$ \\
$\mathrm{~V}$ & $\mathrm{mg} \cdot \mathrm{kg}^{-1}$ & $\mathbf{5 . 9 5}$ & & \\
$\mathrm{Z}$ & $\mathrm{mg} \cdot \mathrm{kg}^{-1}$ & & $\mathbf{0 . 3 4}$ & \\
Halogens & $\%$ & $\mathbf{0 . 3}$ & \\
\hline
\end{tabular}

In Europe, the CEN (European Committee for Standardization) published the standard reference EN 15359 (2011) that developes standards and technical specifications for solid recovered fuels (SRF) for European markets. In this regulation the (SRF) are defined as combustibles obtained from non hazardous waste. It is important to distinguish SRF from RDF as a SRF is only made of non hazardous waste while a RDF is made of any type of waste, hazardous and non hazardous waste. In order to commercialise the SRF, it must be previously classified according to the NCV because it assesses the economic aspects, the $\mathrm{Cl}$ content that evaluates the technological constraints and the $\mathrm{Hg}$ content to calculate the environmental impact. All these values are estimated as defined in CEN/TS 15359 (2011).

Table 6. EN 15359 Classes Classification

\begin{tabular}{ccccccccc}
\hline Classification property & $\begin{array}{c}\text { Statistics } \\
\text { measure }\end{array}$ & $\mathbf{1}$ & $\mathbf{2}$ & $\mathbf{3}$ & $\mathbf{4}$ & $\mathbf{5}$ & $\begin{array}{c}\text { Dry } \\
\text { CF }\end{array}$ \\
\cline { 3 - 8 } & & Average & $\geq 25$ & $\geq 20$ & $\geq 15$ & $\geq 10$ & $\geq 3$ & 20,6 \\
\hline $\begin{array}{c}\text { Net Calorific Value } \\
\left(\mathbf{M J} \cdot \mathbf{k g}^{-1}\right)\end{array}$ & & & & & & & \\
$\mathbf{C l}(\mathbf{\%})$ & Average & $\leq 0.2$ & $\leq 0.6$ & $\leq 1.0$ & $\leq 1.5$ & $\leq 3.0$ & 0.335 \\
$\mathbf{H g}\left(\mathbf{m g} \cdot \mathbf{M J}^{-1}\right)$ & Median & $\leq 0.02$ & $\leq 0.03$ & $\leq 0.08$ & $\leq 0.15$ & $\leq 0.50$ & 4.06 \\
& $80 \%$ percentile & $\leq 0.04$ & $\leq 0.06$ & $\leq 0.16$ & $\leq 0.30$ & $\leq 1.00$ & 4.59 \\
\hline
\end{tabular}

According to the results shown in Table 6, the RDF from the CF of the Onda MBT RF can be considered an SRF. The class code of Onda's SRF with a mean Net Calorific Value of $20.6 \mathrm{MJ} / \mathrm{kg}$, a mean chlorine content of $0.33 \%$ and a median mercury content of $4 \mathrm{mg} / \mathrm{MJ}$ is classified as $\mathrm{NCV} \mathrm{2;} \mathrm{Cl} 2 ; \mathrm{Hg} 5$. All the parameters have acceptable values except for $\mathrm{Hg}$, which should be improved to satisfy the European Norm EN15359:2011.

\subsection{Atmospheric emissions}

Directive 2003/87/EC establishes a scheme for greenhouse gas emission allowance in order to promote reductions in greenhouse gas emissions in a cost-effective and economically efficient manner. This directive specifies a series of actions to reduce greenhouse emissions. It focuses on the reduction of the anthropogenic emissions of greenhouse gases by 8\%, as compared to the levels in 1990, over the period 2008 to 2012. The Directive-specified installations must hold a gas emission permit issued by a competent Authority. The emission calculations will be performed using the following equation: 


$$
\text { Emission }=\text { activity data } * \text { emission factor } * \text { oxidation factor }
$$

The emission factor for biomass shall be zero; therefore the utilization of fuels containing biomass allows the corresponding installation emissions to be subtracted. In the Onda $\mathrm{CF}$, biomass is made up of food and gardening waste and wood, which represent $20.09 \%$ of the total CF (taking into account the wet sample).

The flue gas volume and composition were calculated from the chemical composition of the RF and assuming that the controlled combustion was carried out under stoichiometric conditions. Table 7 shows the flue gas $\mathrm{CO}_{2}$ and $\mathrm{SO}_{2}$ composition per calorific unit. Calculations were performed taking into account the fact that the NCV of anthracite, lignite and the RF are $16.94 \mathrm{MJ} \cdot \mathrm{kg}^{-1}, 16.0 \mathrm{MJ} \cdot \mathrm{kg}^{-1}$ and $21.34 \mathrm{MJ} \cdot \mathrm{kg}^{-1}$ respectively.

Table 7. Comparison of atmospheric emissions using conventional fuels and the dry CF

\begin{tabular}{|c|c|c|c|}
\hline \multirow[t]{2}{*}{ Atmospheric Emissions } & Anthracite & Lignite & DryCF \\
\hline & $\begin{array}{c}\text { VOLUME } \\
\left(\mathrm{Nm}^{3} \cdot \mathrm{Mcal}^{-1}\right)\end{array}$ & $\begin{array}{c}\text { VOLUME } \\
\left(\mathrm{Nm}^{3} \cdot \mathrm{Mcal}^{-}\right)\end{array}$ & $\begin{array}{c}\text { VOLUME } \\
\left(\mathrm{Nm}^{3} \cdot \mathrm{Mcal}^{-1}\right)\end{array}$ \\
\hline $\mathrm{CO}_{2}$ & 0.2123 & 0.1962 & 0.2011 \\
\hline $\mathrm{SO}_{2}$ & 0.0007 & 0.0018 & 0.0001 \\
\hline
\end{tabular}

The $\mathrm{CO}_{2}$ emissions due to $\mathrm{CF}$ combustion must be calculated according to Eq 1 and the subtraction corresponding to biomass combustion must be taken into account. Therefore the CF combustion really generates $0.6908 \mathrm{~m}^{3} \cdot \mathrm{MJ}^{-1}$, a value lower than the one shown in Table 7. Thus, from the point of view of $\mathrm{CO}_{2}$ and $\mathrm{SO}_{2}$ emissions, the SRF obtained from the dry CF presents better results than Anthracite and Lignite.

\section{Conclusions}

The main conclusion of this research work is that the RF produced in the mechanical separation of a MBT plant can be transformed into a fuel which can be energetically exploited, thereby notably reducing the amount of MSW sent to a landfill.

Relying on the results of the characterization of the spring season RF, it is proved that the plant in Onda can reduce its current RF from $43.10 \%$ to $1.63 \%$ if it is processed and transformed into SRF. From the total wet sample RF, $90.70 \%$ is combustible material and $5.52 \%$ is non-combustible recyclable material (glass and metal), so there is only $3.78 \%$ of material that cannot be put to any use.

The SRF thus obtained has some characteristics that make it adequate for use as cocombustible in cement kilns. Its physical composition has an important amount of biodegradable organic matter $(20.09 \%)$, although this percentage can be reduced by increasing the separation efficiency; nevertheless, from the point of view of $\mathrm{CO}_{2}$ emissions, this amount of material is not taken into account. The paper and cardboard fraction is the highest and it is also the fraction with a higher percentage of moisture. If this fraction separation efficiency increases, the percentage of recyclable materials will be raised and the RF moisture will be decreased. 
Regarding the chemical composition of the SRF, it can be said that it satisfies most of the parameters set by different organizations and especially the Spanish Cement Kilns Standard. The ash content is one of the most important parameters. In this case, the SRF exceeds the limits. Nevertheless, it could be improved using mechanical treatments.

The new European regulations on RDF introduce the term SRF and a classification process based on some quality parameters. Onda's SRF is classified as NCV 2; $\mathrm{Cl} 2 ; \mathrm{Hg}$ 5 , having all the parameters acceptable values except for $\mathrm{Hg}$, which should be improved to satisfy the European Norm EN15359:2011.

Further research should be carried out to find out the origin of this high concentration. Finally, according to $\mathrm{CO}_{2}$ and $\mathrm{SO}_{2}$ emissions, the SRF presents better results than Anthracite and Lignite.

\section{Acknowledgments}

The authors thank the Central Service for Scientific Instrumentation of the Universitat Jaume I of Castellón for helping with the ICP Mass.

\section{References}

Anurag G., Smith R., Hill D. 2007. Wastes as co-fuels: The policy framework for solid recovered fuel (SRF) in Europe, with UK implications. Environ. Sci. Technol. 41, 48684874.

Arafat H.A., Jijakli K., Ahsan A. 2013. Environmental performance and energy recovery potential of five processes for municipal solid waste treatment. J. Clean. Prod. http://dx.doi.org/10.1016/j.jclepro.2013.11.071

Aranda A., Ferreira G., Zambrana D., Zabalza I., Llera E. 2012. Estimation of the energy content of the residual fraction refused by MBT plants: a case study in Zaragoza's MBT plant. J. Clean. Prod. 20, 38-46.

Barrena R., d’Imporzano G., Ponsá S., Gea T., Artola A., Vázquez F., Sánchez A., Adani F. 2009. In search of a reliable technique for the determination of the biological stability of the organic matter in the mechanical-biological treated waste. J. Hazard. Mater. 162, 1065-1072.

CEN/TS 15359:2011. Solid Recovered Fuels. Specifications and classes.

CEN/TS 15400:2011. Solid recovered fuels. Methods for the determination of calorific value.

CEN/TS 15403:2011. Solid recovered fuels. Methods for the determination of ash content.

CEN/TS 15407:2011. Solid recovered fuels. Methods for the determination of carbon $(\mathrm{C})$, hydrogen $(\mathrm{H})$ and nitrogen $(\mathrm{N})$ content. 
CEN/TS 15414-3:2011. Solid recovered fuels - Determination of moisture content using the oven dry method - Part 3: Moisture in general analysis sample.

Chang W.C., Chen Y., Chang N. 1998. Comparative evaluation of RDF and MSW incineration. J.Hazard. Mater. 58, 33-45.

Conesa J.A., Rey L., Egea S. 2011. Pollutant Formation and Emissions from Cement Kiln Stack Using a Solid Recovered Fuel from Municipal Solid Waste. Environ. Sci. Technol. 45, 5878-5884.

Directive 2003/87/EC of the European Parliament and of the Council of 13 October 2003 establishing a scheme for greenhouse gas emissions allowance trading within the Community and amending Council Directive 96/61/EC.

Directive 2010/75/EU of the European Parliament and of the Council of 24 November 2010 on industrial emissions (integrated pollution prevention and control).

Elías X. 2004. Hazardous waste presence in the MSW conditions its management. Residuos. 81, 34-49

Eriksson O., Reich M.C., Frostell B., Björklund A., Assefa G., Sundqvist J.O., Granath J., Baky A., Thyselius L. 2005. Municipal solid waste management from a systems perspective. J. Clean. Prod. 13, 241-252.

Erol M., Haykiri-Acma H., Küçükbayrak S. 2010. Calorific value estimation of biomass from their proximate analyses data. Renew. Energ. 35, 170-173.

European Association of Waste Thermal Treatment Companies for Specialised. EURITS Criteria for waste co-incinerated in cement plants. 1996

Finnveden G., Johansson J., Lind P., Moberg A. 2005. Life cycle assessment of energy from solid waste - part 1: general methodology and results. J. Clean. Prod. 13, 3, 213229.

Grau A., Farré O. 2011. Situation and potential of the direct waste energy recovery. Technical study. PER 2011-2020. IDAE.

Genon G., Brizio E. 2008. Perspectives and limits for cement kilns as a destination for RDF. Waste Manage. 28, 2375-2385.

Kaliyan N., Morey R.V. 2009. Factors affecting strength and durability of densified biomass products. Biomass Bioenerg. 33, 337-359.

Koroneos C. J., Nanaki E.A.. 2012. Integrated solid waste management and energy production - a life cycle assessment approach: the case study of the city of Thessaloniki. J. Clean Prod. 27, 141-150

MAGRAMA. Spanish Ministry of Agriculture, Food and Environment. Anual Statistics Report. 2010. Madrid.

Menikpura S.N.M., Sang-Arun J., Bengtsson M. J. Integrated Solid Waste Management: an approach for enhancing climate co-benefits through resource recovery. 
2013. J. Clean. Prod. 58, 1, 34-42.

Murphy J.D., McKeogh E. 2004. Technical, economic and environmental analysis of energy production from municipal solid waste. Renew. Energ. 29, 1043-1057.

Nithikul J., Karthikeyan O,; Visvanathan C. 2011. Reject management from a Mechanical, Biological Treatment plant in Bangkok, Thailand. Resour. Conserv. Recy. $55,417-422$.

Öhman M.; Nordin A. 1998. A new method for quantification of fluidized bed agglomeration tendencies: a sensitivity analysis. Energ. Fuel. 12: 90-94.

Porteous A.2011. Energy from waste incineration- a state of the art emissions review with an emphasis on public acceptability. Appl. Energ. 70, 157-167.

Rotter V.S., Kost T., Winkler J., Bilitewski B. 2004. Material flow analysis of RDFproduction processe. Waste Manage. 24, 1005-1021

Tortosa Masiá A.A., Buhre B.J.P., Gupta R., Wall T.F. 2007.Characterising ash of biomass and waste. Fuel Process. Technol. 88, 1071-1081.

RAL-GZ 724:2012-01. Quality and text instructions Solid Recovered Fuel.

SFS-EN15358 Solid recovered fuels. Quality management systems. Particular requirements for their application to the production of solid recovered fuels. 2011.

UNI 9903-1:2004. Non mineral refuse derived fuels - Specifications and classification.

Wittmaier M., Langer S., Sawilla B. 2009. Possibilities and limitations of life cycle assessment (LCA) in the development of waste utilization systems - Applied examples for a region in Northern Germany. Waste Manage. 29, 1732-1738. 